\title{
Is it still possible to study religion religiously today? Mircea Eliade's religious apologetic account
}

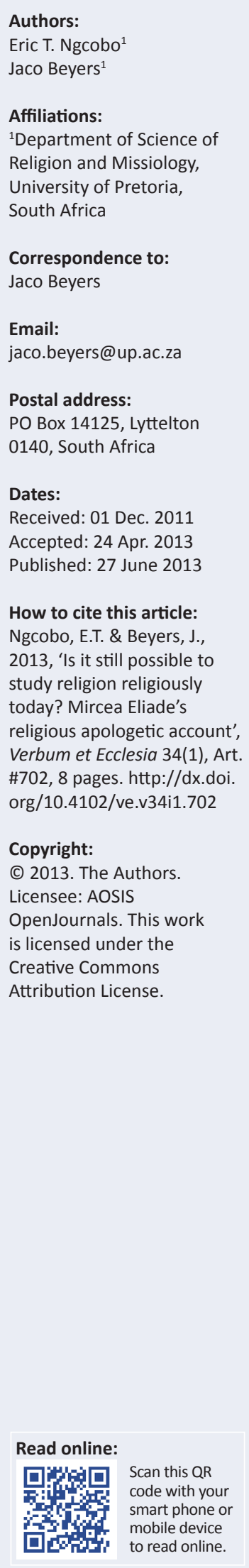

This article reflects on the question whether it is still possible to study religion religiously today or not? This is due to the variety of disciplines' interest in religion and its phenomena. Such interest influenced the study to adopt a new approach that is different from that of religious studies. Both religion and its phenomena, especially myths according to the reductionists, should be treated lesser than they are professed to be. Mircea Eliade on the other hand argues differently, as he stresses on the point that religious phenomena can only be studied under religious spheres alone.

\section{Introduction}

This article discusses the relationship between religion and its phenomena, in particular myth. We shall study the relationship between the two notions in an effort to fuse them as two sides of the same coin. In this article, we shall consider the possibility of studying myth apart from religion and also attempt to do it. We shall therefore analyse whether or not it is still appropriate today to study religion and its phenomena from the perspective of religion. Our aim is to consider the justification of studying myths in this manner and the shortcomings of such an approach.

We shall look at how myths operate and what they portray. We are well aware of the fact that myths are broad and deep, and therefore, we shall not limit or reduce it in this study to any one aspect. One of the fascinating and interesting functions of myths is that it affects social life and the personal behaviour of individuals, and it also determines the identity of cultural groups. Therefore, we shall not benefit from forcing a link between myth and religion. Myths should be freed from religious bondages in order to access their true meaning. In this manner, the view people have of myths will change from sacred to secular, from 'primitive' to intellectual and from fiction to logic.

In the approach of scholars who reduce the understanding of myths to a religious perspective, the reductionists do not mean to deem myth absolutely irreligious but less religious. This approach was supported by a number of scholars, such as Segal, Tylor, Frazer and Bultmann. They believed that this approach would help to reach the deep and broad message conveyed by myth without myth being submissive and subjected to religion. Myth will therefore be addressed as something less than it was thought to be. Myth will be viewed as something less sacred, making it more accessible for study by anyone.

Eliade, a historian of religion, has a different view. According to him, myths and religion are inseparable. They are the two sides of the same coin. Eliade's views differ from those of many other scholars, who think that myths are 'primitive' stories about the 'primitive' world. According to Eliade, 'in societies where myth is still alive, mythic people distinguish myths, or "true stories", from fable, tales, and legends, called "false stories"' (in Allen [1998] 2002:183). Myths are true stories, and they are as alive as the believing community. They are not dead stories which have no place in this modernised world, but they are living and still inspire communities today. They emphasise the importance of life by explaining the existence of humankind and the sources of life, for example God, gods, goddesses and spirits.

Eliade believes that myths are not fictions or fabulous and false stories as reductionists refer to them. For him, 'myths are true stories, they can be related only under certain circumstances, such as only to those who are initiated or only during periods of sacred time' (in Allen [1998] 2002:183). He stresses that myths are true stories, signifying true events, at least to the society that believes the myth. He illustrates this by pointing out symbolisms surrounding religious life that is characterised by myths for he believes that ' $t$ ] he symbol reveals certain aspects of reality, the deepest aspects, which defy any other means of knowledge' (Eliade [1952] 1961:12). These symbols in a myth symbolise a myth archetype. 
Eliade also argues that a myth is kept alive in a religion through rituals. 'For primitive and archaic man, frequently termed "the man of the traditional societies" or homo religiosus, myths are the foundation of his world' (Eliade [1957] 1987:100). The re-living of a myth through ritual establishes and preserves the 'real world' (Lenssen 1980:21). Myths are re-lived through rituals. Rituals are the safeguards of a religion. As long as rituals are there, myths and religion will not lose meaning and vice versa.

Eliade believes that religion is sui generis and autonomous (Yonan 1994:43-44). Myths and mythology are religious by nature. This makes complicated the study of myths without recourse to religion.

\section{What is myth}

The study of myth and mythology is not a recent venture. It has been of interests for centuries, and that interest is still alive today. Many participants from different fields of study or disciplines, including Plato, Segal, Taylor, Bultmann, Edwards, Rahner, Freud, Jung, Malinowski, Levi-Strauss, Eliade and many more, have tried to formulate a definition of the word 'myth'. These different conceptualisations led to the different and complex meanings that have been attached to the word 'myth'. Hence, each individual translates and explains it in the way she or he thinks it should be. Therefore it will be inappropriate to insist on one definition as valid.

The word myth is derived from Greek, mythos, referring to any story narrated without necessarily implications of truth. In early Greek, 'the word mythos [from which our term myth] was derived seems to have meant simple narrative or story without any connotation of truth or falsity' (Richardson \& Bowden 1983:389). The word mythos (a story) meant a narration and a kind of a narration which refers to 'holy history' (Lenssen 1980:23). Therefore mythos is a story that is not bound to a historical record of time, date and logic. A story that is a mythos is mysterious, for its format and actors and actresses are different from those of our present day. As a result, such a story is viewed as one with limited truth.

Mythos was stories narrated orally before they were written down. They were passed from one generation to the next orally, in spoken words. Therefore a more justified way of defining myth must be closely associated with speech because the word mythos normally meant a word, or speech, or blueprint in the early Greek language. Mythos was used to denote narrations addressed to people or the nation. It was mostly used in public speeches. As Batto (1992) argues:

The Greek term mythos referred to a tale or something spoken aloud; encompassed within its semantic range with phenomena as diverse as a public speech, conservation, a proverb, a narrative, and even the plot of a story or play. (p. 4)

Batto here declares that mythos was vocal speech which may also have included proverbs. If Batto is correct, it means that the word mythos is confused with other Greek terms such as (1) epos, which also means a word, speech or message, and the term (2) logos, which means a word, account or talk. However, an epos could not be a mythos because a mythos is not just an account of words or message; it specifically designated a description of such words of speech with wisdom. Myth was words that conveyed to humans an elucidation, introducing them to the uncovered truths of the society. Its task was to alert the community or the nation about prior events.

In Greek philosophy, there was always a clash between myth and logos. It is clear that the traditional attitude of philosophy toward myth is expressed in the contrast mythoslogos, where the latter is intended to signify a rational, analytic, and true account' (Peters 1967:120). Myths were the opposite of logos. Logos indicated true and logical accounts. The validity of myth was contested.

Even so, according to Karl Rahner, myth was treated as mere words or speeches to address people or even to address a single person. Rahner at the same time believes that there is more to myth than just a message, as he (Rahner 1975) argues:

'Myth' meant originally (Greek $\mu$ v́⿴囗o) word, news, language, message, but could also mean an event and history. The word and message of myth are concerned with life, the world and things as a totality, describing their origins, relationships and meaning. More precisely, myth is characterized by the fact that it sees the empirical world and its happenings, and above all man and his action, in the light of a reality which constitutes them, makes them a unity and at the same time transcends them. (pp. 1011-1012)

This additional contribution by Rahner takes us to a new interpretation of the term myth. Though he is describing it as a word or message, he also adds that mythos is an event or history or an episode, occasion, experience, record or an account. According to Rahner, mythos as a word means a word or message or speech, but as a term, it meant events, historical events. The word mythos was used to describe life in the past or in an earlier generation, a sort of chronicle. Myth was providing new insight into well-known answers concerning the truth, forwarding the truth gained through the ages to future generations. Mythos consequently meant wisdom beyond man's comprehension.

We find that, during the course of time, a new development in meaning arose. For as 'from the time of the poet Pindar in the fifth century B.C.E. mythos acquired a connotation of fiction' (Batto 1992:4). Coupe adds that "'myth" originally meant "speech" or "word", but in time what the Greeks called mythos was separated out from, and deemed inferior to, logos' (Coupe 1997:9). Both Batto and Coupe agree that the term myth, at first did not mean what we understand by it today. The term mythos was developed to denote a nuance of fiction or even deemed inferior to logos. Logos will represent something truthful whereas mythos would represent something untruthful or fictional.

Mythos was then distorted as a narration containing illusionary details, a story without facts. It was from then onwards, that it was interpreted as a 'tale'; as Roger Schmidt 
in his Sacred Stories concluded: 'In one sense, myth is simple; a synonym for story, but the term myth is commonly used to signify false tales' (Schmidt 1988:184). This statement by Schmidt demonstrates that this development has transformed myth into something new, the unknown, and changed its meaning completely. Myth as a term was then used to refer to the stories that are rated as ineffectual, unreal, illusory, futile and incredible. Myth therefore lost its sense, both in meaning and importance.

Over time, the term also came to refer to the imaginary stories about God, gods, spirits and legends and the way in which they behave and act with extra-ordinary powers. Compared to Western notions of historiography, this means that myth is seen as unscientific. Spence ([1921] 1994:12) defines mythos as follows: 'A myth is an account of the deeds of a god or supernatural being, usually expressed in terms of primitive thoughts.' As it is expressed in the word 'primitive', myth is just an old form of thinking, which is incompatible with modern views of historiography.

\section{The relationship between myth and religion}

Mythology is multivalent and interdisciplinary. It is studied from different disciplines, and many scholars have given their views on what is to be described as myth and its message. One of the effects of this multi-faceted study is that myth has a variety of meanings in current scholarly thought and that the study of myth and mythology from different disciplinary perspectives enhance the variety of interpretations one could give to myth. The findings prove to us that myth cannot be studied in relationship to religion alone.

However, we would like to emphasise here that some scholars such as Eliade, Rahner and Schutte believe that myth cannot and should not be studied separately from religion since they classify myth under religion. According to them, myth and religion stand in an interrelationship towards one another. In fact, myth plays an important role for one to find faith in a religion because 'only from mythology can we discover the religion, morals, laws ...' (Edwards 1967:435). Myth, therefore, forms the ingredients of faith in any religion. Bultmann (1984) argued that Christian faith and doctrines are formulated mythically. Creeds and confessions are constructed from myth, for example the virgin birth, the resurrection and the ascension (Segal 1999:37). As a result, myth performs the task of connecting the participants of faith to their religion for religious phenomena are represented mythically.

Naturally, myth correlates with religion because both are primarily not about the physical world that relies on science. Both religion and myth are involved in the physical world in a way that is different from the scientific way. Science deals with this physical world directly whereas myths and religion deal with it ultimately. Myth and religion try to reconcile the physical world with the spiritual or imaginable world.
Myth and religion are two phenomena that exist alongside each other, and one cannot explain the one without reference to the other. Segal (2004:13) draws the following conclusion: '[M]yth is here part of religion.' The interrelationship between the two cannot be ignored. The same question could be posed to the Bible, namely whether it could survive without the inclusion of myth. From a religious perspective, the myths in the first book, Genesis 1-3, and the last book, Revelations 20:19-22:5, form the ingredients of the Christian faith. Their omission from the Bible would raise questions concerning the existence of the world, the future world, God and His role in both of these. Therefore, the Christian faith requires these myths to maintain its belief.

In religion itself, there is always a clash between myth and revelation. This normally happens when two religions merge. It is in this way that Paul referred to other religions and beliefs as mythic (see $1 \mathrm{Tm}$ 1:4; 4:7; $2 \mathrm{Tm} 4: 4 ; \mathrm{Tt} 1: 14$ ). This is not something new, for all religious people believe that their religion is a true religion, and they view other religions as mythic or impostors of faith. Most Black Africans believe that their African Traditional Religion (ATR) is a revelation, for it was revealed to their ancestors and transferred to them. According to them, ancestral worship is not a mere practice but a revelation. The same applies to Christianity. Christians believe that Christianity is a universal religion, for it is the only revealed religion in history. It was revealed to them by Jesus Christ, the Son of God. This deems Christianity to be a true religion.

From where we stand, it is clear that no religion is ready to accept myth as the prime formulae and customs of its faith. Most people regard their religion as 'mythic-free'. In contrast, Rahner believes the opposite. His argument is in agreement with that of Eliade. He does not separate myth and revelation. He argues:

The express revelation of God, which culminates in the historical epiphany of Jesus Christ, came to and still comes to men who know of God and Godhead in a mythical way in historically and sociologically conditioned religions ... [And] Without the vivid imagery of mythical notions, the knowledge of God's saving act, which passes from myth to logos and surpasses while absorbing both, would remain an empty thing. And such knowledge is desirable and necessary for the sake of truth. (Rahner 1975: 1010-1015)

Rahner indicates clearly what the relationship between myth and revelation should look like. For him, myth is the only way in which we know revelation. Without myths, we would be without knowledge of God. Rahner assigns to myths a special place in revelation and appreciates their role in religious life. Therefore, since myth and revelation work towards the same purpose, myth and religion belong together, and they are inseparable.

It is, however, interesting to see how thought on religion have developed after Eliade. Asad (2003:182) indicates that it is no longer viable to distinguish between the sacred and secular spheres in reality and claims that religion is concerned only 
with the sacred. According to Asad, religion operates in the sacred as well as the secular spheres. This refutes Durkheim's distinction between the sacred and the profane. Religion is just as active in the private as in the public sphere (Asad 2003:183). The implication of Asad's theory is then that myths would function within religion as well as within the social sphere. They are then by implication open for investigation by religious scholars as well as scholars from other fields of study like sociology and anthropology.

\section{Eliade's point of departure}

Mircea Eliade was a Romanian-born historian of religion who spent most of the latter part of his life in the United States of America, working as a professor at the University of Chicago. He devoted his whole life to studying various religions, traveling around the world.

As a result, he found himself confronted by myths and chose to take them serious as an academic. He wanted to study and interpret myths, and according to him, this can only be done along religious patterns (Eliade [1952] 1961:34). As his point of departure, he wanted to understand their primary message to religious man:

As Eliade affirms in many places, his point of departure is historical data that express mythic and other religious experiences of humankind. Through his phenomenological approach, he attempts to decipher the empirical, historical, mythic data; to describe the phenomena that constitute the mythic world of homo religiosus; and to interpret their religious meaning. (Allen 2002:6)

Eliade's point of departure in studying myths and religion is based on the assumption that a particular myth is trying to convey historical facts to religious man. Homo religious, according to him, represents the 'total-complete-man'. Lenssen (1980) puts it as follows:

His understanding of homo religiosus groups the call for a new humanism, for it is the new humanism which makes possible a return to man's proper nature through recovery of the religious or the sacred. (p. 62)

Homo religiosus is the human being seeking completion. Humans can only manage to find completion if myths are allowed to be active in their life (Eliade 1961:35).

Eliade, therefore, rejects any work done on myths outside of religious studies (Eliade 1987:28). For according to him, homo religiosus is the only option we have to grasp the true meaning of myths (Eliade 1987:100). Myths are part of religion, and they need to be studied from a religious perspective for myths are religious by nature.

\section{Reductionists}

\section{Reductionism}

Reductionism has been used as a tool for obtaining an intellectual grasp on an object of study. Reductionists believe that reductionism is the only way in which we might arrive at truthful meaning. By reducing an untouchable thing to a touchable, an unapproachable to an approachable, a scholar will make it more accessible and relevant.

Yonan views reductionism as 'symptomatic of what we mean by rationality' (Yonan 1994:41). He and others such as Segal, Bultmann and Tylor believe that it is only through reductionism that we may arrive at correct and more concrete and rational answers. They believe that reduction is the means of rationality.

According to the reductionists, religion and its phenomena are not strictly bound to a religious understanding. They maintain that religion can also be discussed from the perspective of social science because religion contains social content. Myth may have philosophical as well as psychological inclinations. Myth is not only about the religious (or spiritual) things, but it also deals with social issues, the issues that affect any being that live in a so-called society. Segal comments as follows:

Certainly social scientists find psychological, anthropological, and sociological content in religion. The richest social scientific interpretations, Freud's, Jung's, and Marx's provide whole glossaries for translating 'religious' terms into secular ones. (Yonan 1994:7)

Segal here argues that religion is not strictly 'religious'. It does not only influence religious life but also other secular spheres of life that have to do with the social. Therefore religious phenomena are to be translated into more secular terms. As a result, bringing about a schism between religion and religious phenomena, such as myths, and social science will mean that scholars are ignoring myth's effect on social reality.

Segal believes that 'religionists would be able to keep the social sciences from the meaning of religion but not from the origin and function of it' (Yonan 1994:7). For Segal, religion can be protected from social science by the religionists, but he insists that, by nature, religion is part of social science, and social science and religion function in the same way in society. The issues addressed by religiosity are the same as those addressed by social science. This is the result of the human condition. One of the possibilities of those causes, according to Segal, could be human conditions.

Humans are trying very hard to make sense of their mysterious lives by engaging themselves in religious activities. Religion becomes their reasonable means for continuing to live a hopeful life. Hence, religion is being relegated from being sacred to social activity.

\section{Reductionists' criticism on Eliade}

Even though the reductionists' aim was to study religion and its phenomena in a new domain, Eliade remained one of their main opponents. Reductionists, especially Segal and Fenton, accused Eliade and the other anti-reductionists (like Rahner and others), who stressed the irreducibility of the sacred, of being ignorant. They said that Eliade is a non-reductionist reductionist for he simplifies the meaning of myth by limiting it to religion alone, which does not do justice to other disciplines. 
Allen investigates one of the well-known reductionists, John Fenton, to illustrate this. Fenton, as a reductionist, believes that it is only reductionism that could provide a clear and fair analysis of myth, without limiting it to one discipline:

[Fenton] in his hermeneutical strivings for synthesis and integration within an irreducibly religious framework of interpretation, and Eliade cannot do justice to anthropological, sociological, psychological, economic, and other approaches that do not assume the irreducibility of the sacred. He translates the contributions of other approaches into his own irreducibly religious framework, simplifying and excluding aspects of other scales of interpretation and explanation that do not privilege the Eliadean perspective ... In Eliade's 'nonreductionist' reductionism, he assumes the irreducibility of the religious and privileges a specific religious perspective ... In doing this, he necessarily reduces the complexity of phenomena to his religious plane of reference. (Allen 2002:29)

Fenton criticises Eliade for his blind-sited criticism on reductionists whereas he himself is a religious 'nonreductionist' reductionist. Eliade, according to Fenton, does no justice to other disciplinary approaches and myths themselves. 'He refuses to reduce the phenomena he interprets as religious to nonreligious scales of interpretation and explanation' (Allen 2002:29). Fenton accuses Eliade of assuming that all myths are religious.

Fenton was not the only one who had some problems with the accusations made by Eliade against reductionism and its approach to myths and religion. Another reductionist, Robert Segal, insists that the concrete measure of interpreting religion is a reductive approach (see Allen 2002:33). Religious phenomena should be explained in a broader form. Segal is of the opinion that research in religion must be done scientifically, which means that there must be no limits and favours. According to Segal, reductionists are not ignorant of the fact that believers in myth believe the validity of the information passed on to them through myths.

According to Segal, even the strongest reductionists do not deny that religious believers believe in the reality of the sacred, the object or referent of their mythic and other religious beliefs (Allen 2002:33).

He carries on by saying the following:

No one denies that religious data also reveal that believers accept the religious basis for the origin, function, and meaning of their phenomena. But the acceptance of the irreducibility of the religious for the religious believer is on the manifest level of description and interpretation. This is a legitimate and even necessary starting point for scholars, including reductionists, but it is not the end point analysis. (Allen 2002:33)

Segal's understanding here affirms that reductionism is a suitable approach to explaining religion and myth. His scientific approach clarifies the classic position in which the study on myth should be done. Reductionism as such is not a problem because reductionists are aware of the validity and the sacredness of religion to believers, and they accept and respect that. Eliade and other anti-reductionists are either blind or stereotyped scholars. Yonan is alert to the sacred space of religion, but he insists that reductionism goes an extra mile, which religionists and anti-reductionists fail to do. He then makes the following claim:

Religionists assume that truth of religion and on that basis determine the origin and function, if not also meaning, of it. When, for example, Eliade (1987:100) praises religion of serving to link humans to the sacred, his praise presupposes the existence of the sacred: he can scarcely be praising religion for opening persons to the sacred unless the sacred exists - the determination of which must surely be on metaphysical grounds. If Eliade can apply his metaphysical views to the determination of the origin and function of religion, so can social science. (Yonan 1994:11)

Segal here finds Eliade at fault for not getting his facts straight. For Segal, Eliade is dwelling on the unknown, and his argumentation is more metaphysical than realistic. Eliade's views on the irreducibility of a religion are lacking the logical proof of occurrence and function. Therefore Eliade and the other religionists do not have a restricted privilege on religion and its phenomena that relegate other disciplines to the outside. The social sciences strongly believe that they have the right of commenting on the unknown or sacred. If the religionists are allowed to, social scientists should also be granted such an opportunity.

Segal is much more interested than others in insisting that reductionism is applicable to religion. He fails to understand why Eliade should stress that the only person to interpret myth must be a believer of the myth.

\section{Eliade as an anti-reductionist Eliade's anti-reductionist assertions}

It is not quite clear whether or not Eliade would have classified himself as a non-reductionist, but from his arguments, it seems highly unlikely since, in them, he did away with reductionism. Scholars such as Frazer, Ryba and especially Fenton thus assumed that he must have been a non-reductionist. Some scholars doubted this label and found it irresponsible to label him as such. They (especially Elzey and Rahner) believed that he was labelled by those who supported reductionism in order to emphasise their divergence. Yonan summarizes Elzey's evaluation of Eliade's position by stating:

Eliade's theory of religion is not simply non-reductionistic . It is overtly anti-reductionistic. It is not an attempt to avoid or invade the challenges of reductionism and it is more than just a protest against the irrelevancy of the social sciences which had no adequate methodological tools for interpreting religion. (Yonan 1994:84)

Elzey argues that Eliade is an anti-reductionist for he acts as an scholar of myths. For Elzey, Eliade did not try to defend religion against social scientists. He just did not support reductionism. Elzey states that Eliade was protesting against reductionist theories and approaches towards religion, claiming that they were irrelevant.

The prime concern for Eliade, according to Yonan (1994:43), is the reductionists' approach to religion in which they 
tried to explain myths without reference to religion and the religion without reference to myth. As Segal believes that religion is sui generis and autonomous, it should be treated as such, Yonan (1994:43-44) points out, because in approaching religion in the way the reductionists do, both religion and myth lose their essence. The statement is supported by Allen (2002):

With regard to Eliade's general approach to reductionism and myth, we may distinguish two related claims: First, for Eliade myth is religious myth; therefore, the most common way to violate the irreducibly mythic dimension of the data is to reduce its irreducibly religious structure and function to some nonreligious plane of reference and explanation ... Second, there are claims about the irreducibility of mythic that go beyond claims about its irreducibly religious nature. (p. 4)

Eliade marries myth and religion as a pair. He believes that myth and religion are indistinguishable and not separable. He argues that myth and religion do not operate independently of each other, but related to one another. Therefore, to try to separate myth and religion as reductionist scholars did will only deplete and impoverish both myth and religion.

Eliade criticises the reductionist approach and strongly stresses the non-reductionist approach to the sacred. He believes that reduction is not an ideal method of studying myth and religion. Therefore, there must be a correct way that will lead to a relevant approach to the study of myths. That approach cannot come from outside of religious circles. Eliade declares that, a 'religious phenomenon will only be recognised as such if it is grasped at its own level, that is to say, if it is studied as something religious' (Allen 2002:8-9). If a religious phenomenon is approached from other angles, from outside of religious circles, misjudgements and misinterpretation are likely to occur. Eliade (1969) argues:

The divergences resulting from an incomplete documentation do not constitute the only difficulty in the dialogue between the historian of religions and his colleagues from other disciplines. It is his very approach which separates him, for instance, from anthropologist or the psychologist. (p. 74)

According to Eliade (1969:74), a particular approach is the only thing that distinguishes the argument of a historian of religion from those of scholars from other disciplines. The social sciences approach, especially that of anthropologists and psychologists (as he stated above), diverges from that of historian of religions.

Eliade as a historian of religion believes that religious phenomena are bound to the religious plane alone, and they must be approached from a religious perspective. He insists that scholars should be believers in the myths they study, which will be the only means through which such a scholar will arrive at adequate conclusions. This emphasis on a scholar as a believer is clearly demonstrated and kept alive by his argument that 'one must believe in the existence of the religious and metaphysical planes' (Allen 2002:9). The effectiveness of personal experience with a religion will limit the chances of unfounded judgments. A person without such experience is, according to him, not qualified for any research on myths and religion. Eliade (1969) believes that nobody other than a scholar of antiquity is qualified to make comments on myth. He summarises:

In short, our best chance of understanding the structure of mythical thought is to study cultures where myth is a 'living thing,' where it constitutes the very ground of religious life; in other words, where myth, far from indicating a fiction, is considered to reveal the truth par excellence. (p. 73)

And that is why he seemed to be in agreement with Jung as he comments on Jung's approach:

Contrary to Freud, who despised religion, Jung was convinced that religious experience has a meaning and a goal, and, accordingly, that it must not be 'explained away' by reductionism. He insisted on the ambivalence of the religious figures in the unconscious ... Moreover, Jung made a careful study of archaic and oriental religions, and his contributions stimulated the researches of many historians of religion. (Eliade 1969:22)

The archaic society is the only place where the study on myth may be employed because it is only in these societies that myths are still alive. In such societies, myth is not passive since people in these societies live their religion every day. These societies do not treat myth in a mythic way but as a living thing. Their everyday lives are directed, promoted and guided by their religious myths. The myth is their past, present and future as well. Segal (1989) adds:

According to Eliade, religion is analyzable in only religious rather than, say, psychological or sociological terms because for believers it is ... By the believer's point of view Eliade seemingly means a believer's conscious, or professed, view of origin, function, or meaning of religion. (p. 6)

Eliade does not eliminate the possibility of analysing religion as long as it is done in religious circles. He emphasises that it is not easy to approach religion and its phenomena from an outside view and that it should rather be done from a believer's point of view. Therefore, a researcher's point of departure must be a believer point of view. Religion must be approached from a believer's perspective. Allen (2002) comments:

Just as 'laymen' are unqualified to judge literature and art on moral grounds, since this involves a 'confusion of planes,' nonbelievers are laypersons unqualified to say anything about mythic and other religious beliefs: 'You cannot judge a spiritual reality without knowing it, and you do not know it without contemplating it on its own plane of existence'. (p. 11)

Non-believers are like laypersons. They are not capable of making any judgment on myth and religion because they would do it from the external viewpoint without any internal reflection. Persons from an outside perspective will not necessary be successful in searching for the true meaning of a myth in a religion because they will be guided by their presumptions. Therefore any hermeneutist will first need to be part of a religion before making any findings. Scholars without the experience of a religion will draw their own conclusions. That is why they need to have experience of that particular religion before conclusions are drawn. 
Eliade finds scholars who favoured reductionism in their studies of religion in error of enforcing their conclusions and findings. He 'criticizes them for reducing the meaning of the religious to its anthropological, sociological, psychological, or historical analysis' (Allen 2002:12). They reduced religion to one of the human sciences, which caused religion to lose its sacredness. As a result, religion turned into something irreligious. Reductionists thus turned this form of faith into just another chronicle, dismantling it as sacred history (as we mentioned above).

Since Eliade believes that myth is part of religion and that these two are sides of the same coin, to interpret them otherwise will damage their validity and open doors to unfair judgments. Myth cannot be translated and interpreted from outside of religion. Myth is simply a part of religion, and they co-exist with other fields. Myth cannot be an anthropological, psychological, sociological or philosophical phenomenon. It belongs to religion alone.

In this, Eliade maintains his argument and insists on the irreducibility of the sacred, and he 'primarily attacks reductionist accounts for being "false"' (Allen 2002:13). He claims that these reductionists make profane, inconvenient and inappropriate claims that dull the true picture of the sacred. They fail to understand the real issue and dwell on their falsified arguments. They make assumptions about what religion is:

Eliade's works contain many criticisms of reductionistic interpretations and explanations that do not do justice to the 'complexity,' 'totality,' 'ambiguity,' and 'unrecognizability' of the sacred, but instead reduce the mythic to some partial, oversimplified, one-sided, or otherwise incomplete perspective. (Allen 2002:13)

The word 'incomplete' is, according to Eliade, the definition of the end-product of reductionism (Allen 2002:13). Reductionism overlooks issues that are related to religion and emphasises the non-religious perspectives, which deem religion irreligious. Freud is one of those whom Eliade believes to have reduced the meaning of myth into one single aspect, as Allen (2002) says:

Eliade criticizes Freud and some other reductionists for focusing on only one, limited valorization of a complex, multivalent, inexhaustible religious symbolism and then claiming that their very narrow interpretation or explanation is sufficient. (p. 13)

Freud and others narrow myth down to symbolism alone (or allegories) and overlook their role in the religious sphere. One should be careful here because Eliade himself uses such arguments as he believes myths to be symbolic by nature. In order to maintain his argument, Eliade tries to interpret the symbolic nature of a myth into reality. The difference between the two sides is that Eliade (1987:100) tries to interpret myths symbolically on the basis of faith in religion whereas Freud and others separate them from religion. This separation or reduction reduces the true meaning of a myth.

Eliade thinks that religious sectors themselves are the perfect place where one can perform the analysis of religious phenomena (see Allen 2002:11). A religion is religious by nature and it and its phenomena should always be treated as such. Even though Eliade rejects any exploration of a myth outside of the religious sphere, he is well aware that myths do not only affect the religious space alone. He knows that religiosity affects all aspects of life. He also knows that there are no entirely or solely religious phenomena. The nonreductionist approach in religion does not mean that religion is totally unapproachable. Religion in this manner is sacred but still approachable, and it always revolves around society. In The quest: History and meaning in religion, Eliade (1969) states:

This does not mean, of course, that a religious phenomenon can be understood outside of its 'history,' that is, outside of its cultural and socio-economic context. There is no such thing as a 'pure' religious datum, outside of history, for there is no such thing as a human datum that is not at the same time a historical datum. Every religious experience is expressed and transmitted in a particular historical context. But admitting the historicity of religious experiences does not imply that they are reducible to non-religious forms of behavior. Stating that a religious datum is always a historical datum does not mean that it is reducible to a non-religious history, for example to an economic, social, or political history. (p. 7)

It is for this reason that Eliade is regarded as a great thinker. He is not locked up in the stereotyped channels that will only guide him to defend religion; he at the same time still maintains his standpoint. He knows that there is no such thing as a purely religious phenomenon. All phenomena contribute on the fulfilment of assortments of life. Nevertheless, Eliade thinks:

[that] it would be hopeless to try and explain religion in terms of any one of those basic functions which are really no more than another way of saying what a man is. (Allen 2002:18)

Elzey states:

Eliade maintained, nonetheless, that "the "sacred" is an element in the structure of consciousness and not a stage in the history of consciousness.' Religion was thus as essential to modern humans as to archaic humans. (Yonan 1994:91)

The true analysis of mankind and religion is based on religious phenomena. This means that religious people are as religiously conscious as modern (or non-religious) people are for religion points to the sacred as a means of consciousness. The sacred manifests the consciousness of the archaic society as the building block of such consciousness. Eliade links the perception of the archaic society to that of the modern, in that archaic consciousness is not outdated, primitive and primordial as some think. Therefore, Eliade rejects the reductionist approach and finds it not applicable to religion. In his PhD thesis, Myth and philosophy, Lenssen (1980) states:

He [Eliade] finds that in primitive and archaic society, 'myth is thought to express the absolute truth; because it narrates sacred history ... myth is a true history of what came to pass at the beginning of time.' (p. 23)

He [Eliade] is more specific, understanding myth as that which 'tells how ... a reality came into existence, be it the whole of reality, the cosmos, or only a fragment of reality ... Myth is a record of events that founded the world, that are responsible for the way the world is.' (p. 23)

According to Eliade, the archaic society presents the 'true' believers of myth. They believe in the absoluteness of the 
truths provided to them by myth. According to them, the information that is handed on to them by myths is infallible. This is so simple because myth narrates to them their sacred history, and they are able to know about the reality of their existence through myth. Myth for them is the record of the events that form the foundation of their world. Through myth, they can be able to trace their history and the origins of the world. This fact cannot be reduced to something it is not.

\section{Conclusion}

We conclude by stating that myth is religious in nature. Therefore it cannot be addressed and studied separately from religion, even though myth affects as many aspects of life as other disciplines. This is due to the fact that religion affects all aspects of life. Religion defines types of food, clothing, behaviour, communication, business, et cetera. Therefore religion covers and serves all assortments of life. As long as there is religion, there will always be myth and vice versa.

Myth does not stand as an entity outside of religion. The more we separate the two from each other, the more we steal meaning from them for they are not self-defined, but they define each other. They owe it to each other to remain meaningful and relevant. They cannot be separated, and if we were to make our theology meaningfully and relevant, we would not strive to reduce myth into something less religious. Theology should be able to translate its own religious myths and apply them to everyday life and that of the people. That will start with accepting and appreciating myth in religion and acknowledging its role in helping the believer find faith in religion; for without myth there is no religion.

Therefore, every religion must accept and make peace with the fact that it contains myths. Only then can it be able to interpret those myths in a mythical and meaningful way. Both religion and its promoters must treat myth, mythically, for says Schutte (2006):

the preacher/liturgist is the facilitator in translating the myth into the idiom that [his] audience can relate ... God cannot be met in dogmas, creeds and teachings about God. God can only be met in the experience with God ... This experience of myth provides entrée to the experience of God. (p. 603)

Without myths, there is no experience of God, and without God, there is no religion. Therefore, myths are the foundations and basis for one to find faith in a religion.

Therefore myth and religion cannot be separated or studied apart from each other. This marks the difference between reductionists and Eliade. Yonan summarises the difference between Eliade and reductionists as follows:

Religionists who follow the paradigm example of Mircea Eliade argue against and reject the reductive explanations of social sciences. They claim, [as] Segal argues that (1) religion is a sui generis and autonomous domain of study, (2) that religion can be fully understood only after the believer's irreducible point of view regarding the sacred has been endorsed, and (3) that the truth of religion is beyond explanation ... [Whereas] The reductionism argue that Segal defend is defined negatively by arguing that (1) religion is not a sui generis and autonomous domain of study, (2) that religion cannot be fully understood only from the believer's privileged access point of view, and (3) the truth of religion is not beyond explanation. (Yonan 1994:43-44)

The only thing that distinguishes Eliade from reductionists is his approach. Reductionists treat religion just like any other object of study. They believe that religion has no sacred space or truth claim. They stress that religion is not sui generis and an independent domain of study, but one amongst many.

Such an approach is not justified since it is not safe for religion, and it does not treat religion and its phenomena with respect. On the contrary, it reduces both religion and myth into something they are not. Consequently, religionists stand on this, that religion is irreducible and religious by nature. Religious aspects cannot be approached from any direction but religion itself. This will prevent the compromise of religious truths.

\section{Acknowledgements Competing interests}

The authors declare that they have no financial or personal relationship(s) that may have inappropriately influenced them in writing this article.

\section{Authors' contributions}

E.T.N. (University of Pretoria) completed a masters degree under the supervision of J.B. (University of Pretoria). A summary of the mini-dissertation is presented in an article format. E.T.N. did most of the research whilst J.B. gave direction as to the compilation of arguments.

\section{References}

Allen, D., [1998] 2002, Myth and religion in Mircea Eliade, Routledge, New York.

Asad, T., 2003, Formations of the secular: Christianity, Islam and modernity, Stanford University Press, Stanford.

Batto, B.F., 1992, Slaying the dragon: Mythmaking in the Biblical tradition, John Knox Press, Louisville.

Bultmann, R., 1984, New Testament and mythology and other basic writings, SCM Press, London.

Coupe, L., 1997, Myth, Clays Ltd, London. http://dx.doi.org/10.4324/9780203286005, PMid:9225464

Edwards, P., 1967, sv 'Myth', Encyclopedia of Philosophy, vol. 5, pp. 434-437, The Macmillan Company \& The Free Press, New York.

Eliade, M., [1952] 1961, Images and symbols, Harvill Press, London.

Eliade, M., 1969, The quest: History and meaning in religion, The University of Chicago Press, Chicago.

Eliade, M., [1957] 1987, The sacred and the profane, Harcourt Books, Orlando.

Lenssen, M.C., 1980, Myth and philosophy: The use of myth in the thought of Eliade, Schelling and Ricoeur, University Microfilms International, Evanston.

Peters, F.E., 1967, Greek philosophical terms: A historian lexicon, New York University Press, New York.

Rahner, K., 1975, sv 'Myth', Encyclopedia of theology: A concise sacramentum mundi, pp. 1011-1016, Burns \& Oates, London.

Richardson, A. \& Bowden, J., 1983, sv 'Myth', A new dictionary of Christian theology, pp. 389-391, SCM Press LTD, London.

Schmidt, R., 1988, Sacred stories: Exploring religion, 2nd edn., Wadsworth Publishers, Belmont.

Schutte, P.J.W., 2006, 'At the foot of Mount Olympus: A theory on myth', HTS Teologiese Studies/Theological Studies 62(2), 577-605. http://dx.doi.org/10.4102/hts. v62i 2.364

Segal, R.A., 1989, Religion and the social sciences: Essays on the confrontation, Scholars Press, Atlanta.

Segal, R.A., 1999, Theorizing about myth, University of Massachusetts Press, Amherst. Segal, R.A., 2004, Myth: A very short introduction, Oxford University Press, London.

Spence, L., [1921] 1994, Introduction to mythology: Myths and legends, The Guernsey Press Co Ltd, London.

Yonan, E.A., 1994, Religion and reductionism: Essay on Eliade, Segal, and the challenge social science for the study of religion, E.J. Brill, Leiden. 